\title{
TREATMENT OF POSTINFECTIOUS IRRITABLE BOWEL SYNDROME AND NONINFECTIVE IRRITABLE BOWEL SYNDROME WITH MESALAZINE
}

\author{
Mauro BAFUTT0 ${ }^{1}$, José Roberto de ALMEIDA², Nayle Vilela LEITE ${ }^{3}$, Enio Chaves OLIVEIRA4, \\ Salustiano GABRIEL-NETO ${ }^{4}$ and Joffre REZENDE-FILHO²
}

\begin{abstract}
Context - Recent studies support the hypothesis that postinfectious irritable bowel syndrome and some irritable bowel syndrome patients display persistent signs of minor mucosal inflammation. Mesalazine has intestinal anti-inflammatory properties including cyclooxygenase and prostaglandin inhibition. The effects of mesalazine on postinfectious irritable bowel syndrome and noninfective irritable bowel syndrome patients are still unknown. Objective - To observe the effects of mesalazine on postinfectious irritable bowel syndrome and noninfective irritable bowel syndrome with diarrhea patients. Methods - Based on Rome III criteria, 61 irritable bowel syndrome with diarrhea patients (18 years old or more) were included in the evaluation. Patients were divided into two groups: postinfectious irritable bowel syndrome group, with 18 patients medicated with mesalazine $800 \mathrm{mg} 3$ times a day for 30 days; noninfective irritable bowel syndrome group, with 43 patients medicated with mesalazine $800 \mathrm{mg} 3$ times a day for 30 days. Symptom evaluations at baseline and after treatment were performed by means of a four-point Likert scale including stool frequency, stool form and consistency (Bristol Stool Scale), abdominal pain and distension (maximum score: 16; minimum score: 4). Results - Postinfectious irritable bowel syndrome group presented a statistically significant reduction of the total symptom score $(P<0.0001)$. The stool frequency was significantly reduced $(P<0.0001)$, and stool consistency, improved $(P<0.0001)$. Abdominal pain $(P<0.0001)$ and abdominal distension were significantly reduced $(P<0.0001)$. Noninfective irritable bowel syndrome group presented a statistically significant reduction of total symptom score $(P<0.0001)$. Also, the stool frequency was significantly reduced $(P<0.0001)$ and stool consistency, improved $(P<0.0001)$. Abdominal pain $(P<0.0001)$ and abdominal distention were significantly reduced $(P<0.0001)$. There was no statistical difference between postinfectious irritable bowel syndrome group and noninfective irritable bowel syndrome group on total symptom score results at 30th day of therapy with mesalazine $800 \mathrm{mg} 3$ times a day. $(P=0.13)$. Conclusion - Mesalazine reduced key symptoms of postinfectious irritable bowel syndrome and noninfective irritable bowel syndrome with diarrhea patients.
\end{abstract}

HEADINGS - Inflammatory bowel diseases. Irritable bowel syndrome. Mesalamine.

\section{INTRODUCTION}

Acute infectious gastroenteritis is the strongest known risk factor for the development of irritable bowel syndrome $(\text { IBS })^{(3)}$. Six percent to $17 \%$ of unselected IBS patients believe their symptoms began with an infection, which is supported by prospective studies that show an incidence of postinfectious irritable bowel syndrome (PI-IBS) of $4 \%$ to $31 \%$ following bacterial gastroenteritis ${ }^{(25)}$.

A number of risk factors have been associated with the development of PI-IBS, including the virulence of the pathogen, younger age, female sex, the long duration of the initial illness and the presence of psychological disturbances ${ }^{(3)}$. PI-IBS has been reported after Campylobacter, Salmonella, and Shigella infections.
Serial biopsies after Campylobacter jejuni gastroenteritis show an initial inflammatory infiltrate, with an increase in enterochromaffin cells (EC), which in most cases subsides over the next 6 months ${ }^{(25)}$.

Patients who develop IBS show increased numbers of EC, and lymphocyte cell counts at 3 months compared to those who do not develop IBS ${ }^{(18,25)}$. Individuals with PI-IBS are a clinically distinct subgroup characterized by diarrheal symptoms, less psychiatric illness, and increased serotonin-containing EC compared to those with non-PI-IBS ${ }^{(8)}$.

The increase in EC concentrations associated with PI-IBS may contribute to gastrointestinal symptoms through serotonin-mediated mechanisms ${ }^{(1,6)}$. As EC are the primary source of intestinal serotonin - a

Study carried out at Instituto Goiano de Gastroenterologia, Goiânia, GO, Brasil. The authors declare no conflict of interest.

'Disciplina de Gastroenterologia, Faculdade de Medicina, Universidade Federal de Goiás (UFGO); ${ }^{2}$ Disciplina de Gastroenterologia, Faculdade de Medicina, Universidade Federal de Pernambuco, Recife, PE; ${ }^{3}$ Instituto Goiano de Gastroenterologia, Goiânia, GO; ${ }^{4}$ Departamento de Cirurgia, Faculdade de Medicina, UFGO, Goiânia, GO, Brasil.

Correspondence: Dr. Mauro Bafutto - Rua 246, 25 - Setor Coimbra - 74535-170 - Goiânia, GO, Brasil - E-mail: maurobafutto@yahoo.com.br 
neurotransmitter that stimulates enterocyte secretions and peristalsis - it is conceivable that increased cell numbers could lead to increased serotonin levels and subsequent diarrheal symptoms ${ }^{(23)}$. Indeed, patients with PI-IBS have shown elevated postprandial plasma levels of serotonin compared to patients with IBS with constipation (IBS-C) or healthy volunteers ${ }^{(9,13,22)}$.

Recent studies support the hypothesis that Th2 cytokines induce muscle hypercontractility during infection by a direct action on smooth muscle. The maintenance of hypercontractility results from Th2 cytokine-induced expression of transforming growth factor (TGF-beta1) and the subsequent upregulation of cyclooxygenase 2 (COX-2) and prostaglandin $\mathrm{E}_{2}$ (PGE-2) at the level of the smooth muscle ${ }^{(1)}$. The same studies also support that COX-2 inhibitors attenuated TGF-beta1-induced muscle hypercontractility ${ }^{(1)}$.

Mesalazine has intestinal anti-inflammatory properties including COX and prostaglandin (PG) linhibition. The effects of mesalazine on PI-IBS and noninfective IBS patients are still unknown and, to the best of our knowledge, the present study is the first to address the effect of mesalazine on PI-IBS.

\section{METHODS}

Based on Rome III (Figure 1) criteria, 61 IBS patients with diarrhea (IBS-D) (Figure 2), 18 years old or more, were included (Table 1). To exclude organic diseases, all patients underwent colonoscopy, stool culture, serum anti-endomisium antibody, lactose tolerance test and ova and parasite exam. Patients were divided into two groups: PI-IBS group (PIG), with 18 patients medicated with mesalazine $800 \mathrm{mg} 3$ times a day for 30 days; non-infective IBS group (NIG), with 43 patients medicated with mesalazine $800 \mathrm{mg} 3$ times a day for 30 days. Drugs that might have any effect on intestinal motility or secretion were not allowed. Symptom evaluations at baseline and after treatment were performed by means of a 4. Likert scale (Figure 3), including stool frequency, stool form and consistency (Bristol Stool Scale), abdominal pain and distension (maximum score: 16; minimum score: 4). Paired $t$ tests were used for statistical analyses.

This study was approved by the Ethics Committee in Human and Animal Research of Hospital Geral de Goiânia - CEPHA,

TABLE 1. Patients' demographic data and patients score at baseline

\begin{tabular}{lcc}
\hline Groups/patients & NIG & PIG \\
\hline Age (mean) & 46 & 42 \\
Males & 13 & 7 \\
Females & 30 & 11 \\
Stool frequency score (mean) & 2.79 & 2.44 \\
Stool form and consistency score (mean) & 3.19 & 3.28 \\
Abdominal pain score (mean) & 2.58 & 2.22 \\
Abdominal distension score (mean) & 2.26 & 2.33 \\
Total & 43 & 18 \\
\hline
\end{tabular}

NIG - non-infective IBS group

PIG - PI-IBS group

\begin{tabular}{|lcccc|}
\hline & 1 & 2 & 3 & 4 \\
\cline { 2 - 5 } 1. Stool frequency & $\leq 2$ & 3 & 4 to 5 & $>5$ \\
2. Stool form & $\leq 4$ & 5 & 6 & 7 \\
and consistency & & & & \\
3. Abdominal pain & Absent & Mild & Moderate & Severe \\
4. Abdominal distension & Absent & Mild & Moderate & Severe \\
\hline
\end{tabular}

FIGURE 3. The symptom score evaluation submitted to all of the two groups of evaluated patients before and after 30 days of therapy (minimum score: 4 ; maximum score: 16 )

Recurrent abdominal pain or discomfort* at least 3 days/month in the last 3 months associated with two or more of the following:

1. improvement with defecation

2. onset associated with a change in frequency of stool

3. onset associated with a change in form (appearance) of stool

In pathophysiology research and clinical trials, a pain/discomfort frequency of at least

2 days a week during screening evaluation is recommended for subject eligibility

"discomfort" means an uncomfortable sensation not described as pain

** criterion fulfilled for the last 3 months with symptom onset at least 6 months prior to diagnosis

FIGURE 1. Diagnostic criterion** for irritable bowel syndrome

In order to subtype patients according to bowel habit for research or clinical trials, the following subclassifications may be used (Bristol Stool Form Scale). The validity and stability of such subtypes over time is unknown and should be subjects of future research.

1. IBS-C: hard or lump stools ${ }^{\mathrm{a}}$ at least $25 \%$ and loose (mushy) or watery stools ${ }^{\mathrm{b}}<25 \%$ of bowel movements*

2. IBS-D: loose (mushy) or watery stools ${ }^{\mathrm{b}}$ at least $25 \%$ and hard or lumpy stool ${ }^{\mathrm{a}}<25 \%$ of bowel movements*

3. IBS-M: hard or lumpy stools ${ }^{\mathrm{a}}$ at least $25 \%$ and loose (mushy) or watery stools ${ }^{\mathrm{b}}$ at least $25 \%$ of bowel movements*

4. Unsubtyped IBS: insufficient abnormality of stool consistency to meet criteria for IBS-C, D, or M*

* In the absence of antidiarrheal or laxative use

IBS-C: irritable bowel syndrome with constipation;

IBS-D: irritable bowel syndrome with diarrhea;

IBS-M: mixed irritable bowel syndrome

FIGURE 2. Subtyping irritable bowel syndrome by predominant stool pattern 
Goiânia, GO, Brazil, in August, 12, 2008 (Protocol CEPHA HGG 381/08) and was conducted at offices and at Research Center of Instituto Goiano de Gastroenterologia. All patients answered previously to an Informed Consent. The period of time for data collection was from August/2008 to December/2008.

\section{RESULTS}

NIG presented a statistically significant reduction $(P<0.0001)$ of the total symptom score (Figure 4). Also, the stool frequency (Table 2) was significantly reduced $(P<0.0001)$ and the stool consistency, improved $(\mathrm{P}<0.0001)$. The abdominal pain $(P<0.0001)$ and abdominal distention were significantly reduced $(P<0.0001)$. PIG presented a statistically significant reduction $(P<0.0001)$ of the total symptom (Figure 5). The stool frequency (Table 3 ) was significantly reduced $(P<0.0001)$ and the stool consistency, improved $(P<0.0001)$. Abdominal pain $(P<0.0001)$ and abdominal distention were significantly reduced $(P<0.0001)$.

Groups PIG and NIG showed no significant statistical difference on total symptom score at 30th day after mesalazine treatment (Figure 6).

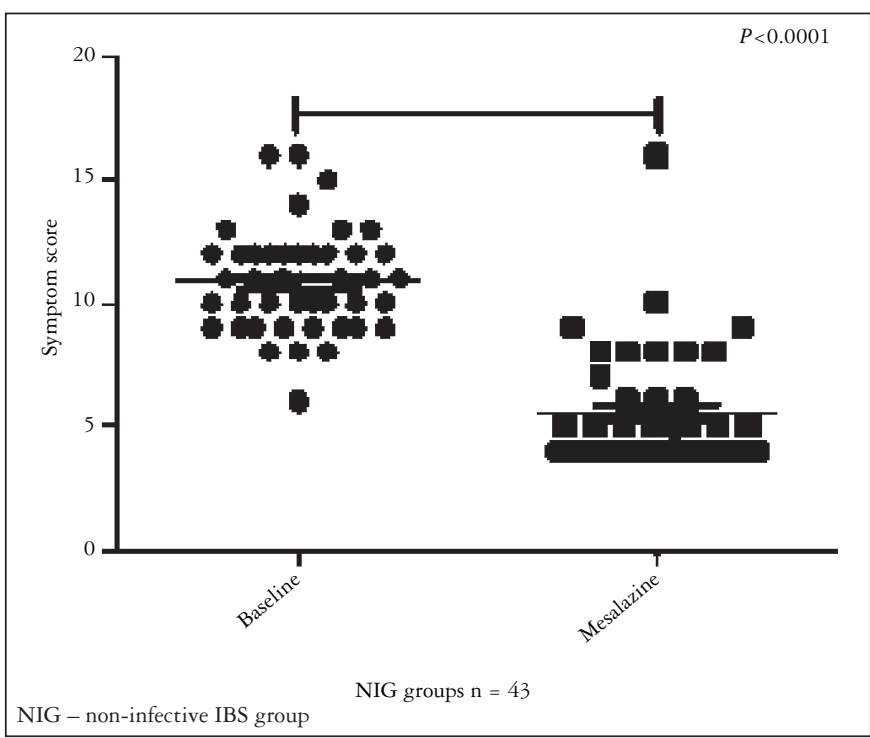

FIGURE 4. NIG total symptom score at baseline and at 30th day therapy with mesalazine $800 \mathrm{mg} 3$ times a day

TABLE 2. NIG patients score of symptoms before and at 30th day with mesalazine $800 \mathrm{mg} 3$ times a day

\begin{tabular}{lcc}
\hline Symptoms & Before & 30th day \\
\hline Stool frequency score - mean (SD) & $2.79(0.67)$ & $1.44(0.70)^{*}$ \\
Stool form and consistency score - mean & $3.19(0.55)$ & $1.60(0.82)^{*}$ \\
(SD) & & \\
Abdominal pain score - mean (SD) & $2.58(0.82)$ & $1.35(0.61)^{*}$ \\
Abdominal distension score - mean (SD) & $2.26(0.88)$ & $1.66(0.64)^{*}$ \\
Total & 43 & 43 \\
\hline
\end{tabular}

$* P<0.0001$

NIG - non-infective IBS group

$\mathrm{SD}=$ standard deviation

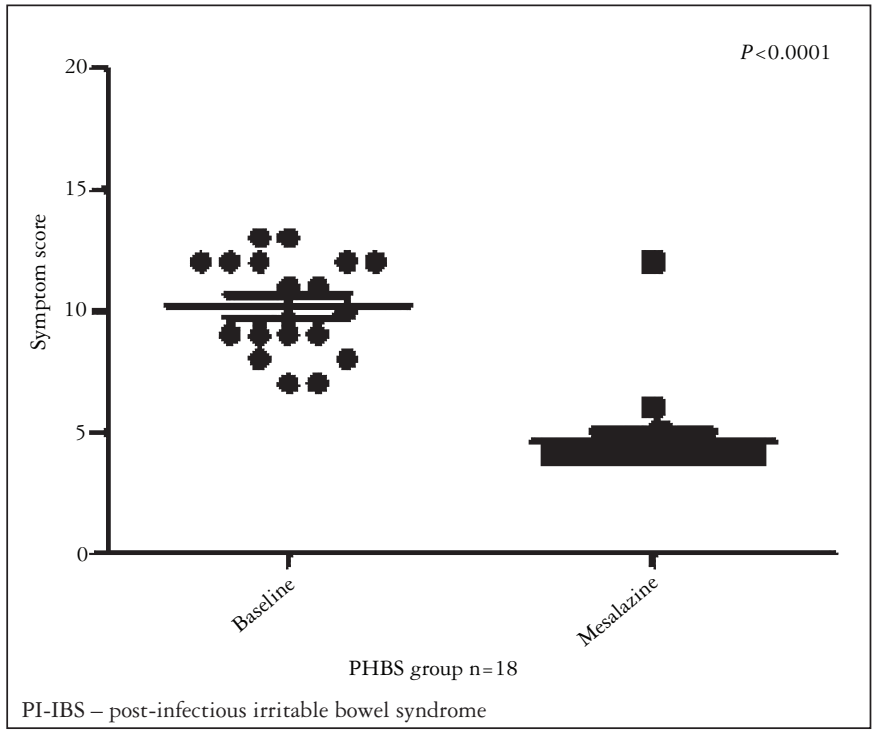

FIGURE 5. PI-IBS group total symptom score at baseline and at 30th day therapy with mesalazine $800 \mathrm{mg} 3$ times a day.

TABLE 3. PIG patients score of symptoms before and at 30th day with mesalazine $800 \mathrm{mg} 3$ times a day

\begin{tabular}{lcc}
\hline Symptoms & Before & 30th day \\
\hline Stool frequency score - mean (SD) & $2.44(0.62)$ & $1.11(0.47)^{*}$ \\
Stool form and consistency score - mean & $3.28(0.57)$ & $1.11(0.47)^{*}$ \\
(SD) & & \\
Abdominal pain score - mean (SD) & $2.22(0.73)$ & $1.17(0.51)^{*}$ \\
Abdominal distension score - mean (SD) & $2.33(0.84)$ & $1.11(0.32)^{*}$ \\
Total & 18 & 18 \\
\hline
\end{tabular}

$* P<0.0001$

PIG - PI-IBS group

$\mathrm{SD}=$ standard deviation.

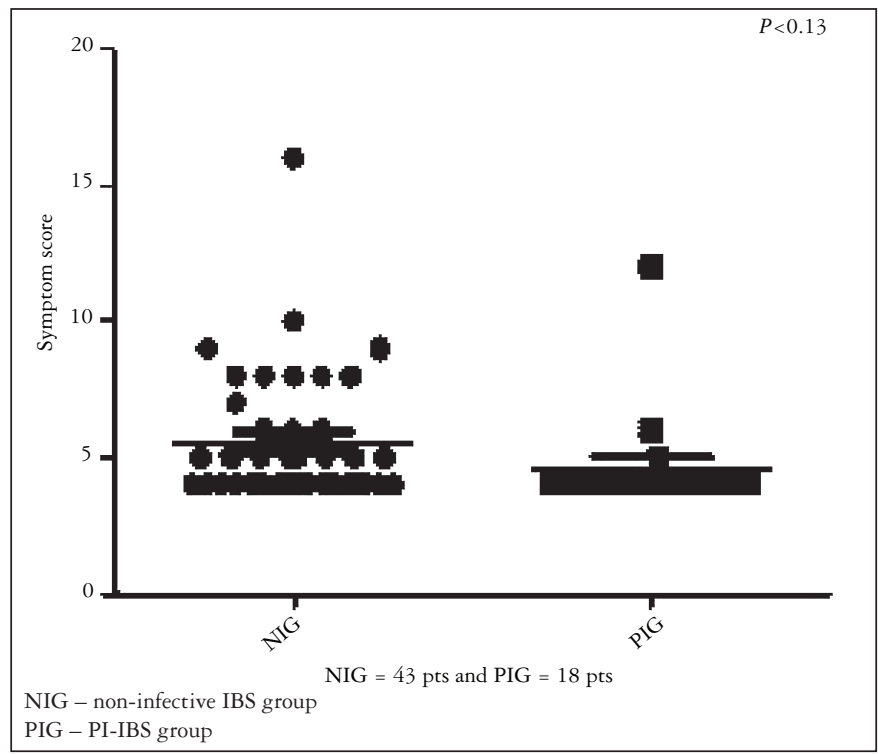

FIGURE 6. Results of NIG and PIG total symptom score at 30th day therapy with mesalazine $800 \mathrm{mg} 3$ times a day 


\section{DISCUSSION}

A unifying hypothesis to explain the pathogenesis of IBS remains elusive. Alterations in gastrointestinal motor function, enhanced visceral perception of painful stimuli and psychosocial factors are considered key contributors to symptom generation in IBS $(2,7,12,14,24)$. Recently, recognized factors include reduced ability to expel intestinal gas, altered central processing of afferent signals and intestinal inflammation.

While routine histological examination reveals no significant colonic mucosal abnormality on the majority of these patients, recent quantitative histological, immunohistochemical and ultrastructural analyses provide evidence of subtle morphologic changes in these patients ${ }^{(2)}$.

There are numerous studies indicating that mucosal biopsies in both PI-IBS and IBS-D show increased numbers of CD3 ${ }^{+}$ lymphocytes ${ }^{(5,8)}$. Different researchers have looked at different classes of immunocytes, but there is a broad agreement on the increase in $\mathrm{CD}^{+}$lymphocytes; also, increases in $\mathrm{CD} 25^{+}$ lymphocytes were shown, indicating the presence interleukin-2 receptor, a marker of activated lymphocytes ${ }^{(5)}$. Patients who developed PI-IBS had higher interleukin 1B concentrations compared to those who had not had an acute episode of diarrhea ${ }^{(13)}$.

In addition to increased concentrations of inflammatory mediators and cells, increased small bowel permeability may also be involved in pathogenesis of PI-IBS. Intestinal permeability, determined by the ratio of lactulose to manitol excreted in urine, was significantly higher in PI-IBS patients compared to controls ${ }^{(22)}$. Several authors have suggested that increased intestinal permeability may allow the access of bacterial and luminal antigens to the submucosa, which could perpetuate chronic inflammation and disrupt enteric sensation and motility, that have been implicated in the pathogenesis of $\operatorname{IBS}^{(7,14,17,24)}$

Recent studies support the hypothesis that Th2 cytokines induce muscle hypercontractility during infection by a direct action on smooth muscle. The maintenance of hypercontractility results from Th2 cytokine-induced expression of the transforming growth factor (TGF-beta1) and the subsequent upregulation of COX-2 and PGE-2 at the level of the smooth muscle ${ }^{(1)}$. The same studies also support that COX-2 inhibitors attenuated TGF-beta1-induced muscle hypercontractility ${ }^{(1)}$.

Mesalazine is known to have anti-inflammatory properties and is used in the treatment of inflammatory bowel diseases. Although its exact mechanism are still unknown ${ }^{(10,20)}$, several potential mechanisms have been suggested, including 5 -aminosalicylate-induced inhibition of inflammation by interfering with the metabolism of arachidonic acid, prevention of mucosal generation of leukotrienes and $\mathrm{PG}^{(26)}$ scavenging of free radicals ${ }^{(21,26)}$ and mechanisms only recently identified involving inhibition of nuclear factor-kappaB $(\mathrm{NF \kappa B})$ and induction of apoptosis ${ }^{(4,15,19,27,28)}$.

Further properties include changes in the production of immune globulins and diminished production of interleukin-1, as well as partial inhibition of platelet activating factor (PAF) expression, resulting in a decrease in leucocyte trafficking ${ }^{(16)}$. Moreover there are evidences that mesalazine has a potential inhibition on mast cell histamine release ${ }^{(11)}$.

In this study, mesalazine, compared to baseline, presented clinical improvement of stool frequency, stool form and consistency (Bristol Stool Scale), abdominal pain and abdominal distension in PI-IBS and non-infective IBS-D patients. There was no statistical difference when comparing the results of total symptom score of PI-IBS and noninfective IBS-D patients.

The limitations of this study was the small number of IBS-PI patients (18) compared to non-infective IBS-D (43), and the follow-up period of 30 days using mesalazine, that might increase the possibility of placebo effect.

Even considering these limitations, we observed good clinical results with mesalazine, an anti-inflammatory drug, in PI-IBS and non-infective IBS-D, supporting previous studies that suggest a low grade bowel inflammation in these groups of patients.

In conclusion, mesalazine reduced key symptoms of PI-IBS and noninfective IBS-D patients. These preliminary results warrant further larger placebo-controlled studies. 
Bafutto M, Almeida JR, Leite NV, Oliveira EC, Gabriel-Neto S, Rezende-Filho J. Tratamento da síndrome do intestino irritável pós-infecciosa e da síndrome do intestino irritável não-infecciosa com mesalazina. Arq Gastroenterol. 2011;48(1):36-40.

RESUMO - Contexto - Estudos recentes sustentam a hipótese que a síndrome do intestino irritável pós-infecciosa e alguns pacientes com síndrome do intestino irritável mostram sinais menores de inflamação persistente da mucosa. A mesalazina tem propriedades anti-inflamatórias intestinais, incluindo a inibição da ciclooxigenase e das prostaglandinas. Os efeitos da mesalazina na síndrome do intestino irritável pós-infecciosa e em pacientes com síndrome do intestino irritável não-infecciosa ainda são desconhecidos. Objetivo - Observar os efeitos da mesalazina em pacientes com síndrome do intestino irritável pós-infecciosa e síndrome do intestino irritável com diarréia não-infecciosa. Métodos - Com base nos critérios de Roma III, 61 pacientes síndrome do intestino irritável acompanhado de diarréia (18 anos ou mais de idade) foram incluídos na avaliação. Os pacientes foram divididos em dois grupos: grupo síndrome do intestino irritável pós-infecciosa, com 18 pacientes medicados com mesalazina $800 \mathrm{mg} 3$ vezes ao dia por 30 dias; grupo síndrome do intestino irritável não-infecciosa, com 43 pacientes medicados com mesalazina $800 \mathrm{mg} 3$ vezes ao dia por 30 dias. Avaliações dos sintomas no início e após o tratamento foram realizadas por meio de uma escala Likert de 4 pontos, incluindo a frequência das evacuações, forma e consistência das fezes (Bristol Stool Scale), dor e distensão abdominal (pontuação máxima: 16; pontuação mínima: 4). Resultados - O grupo síndrome do intestino irritável pós-infecciosa apresentou redução estatisticamente significante do escore total de $\operatorname{sintomas~}(P<0,0001)$. A frequência de evacuações foi significativamente reduzida $(P<0,0001)$ e a consistência das fezes melhoraram $(P<0,0001)$. Dor abdominal $(P<0,0001)$ e distensão abdominal foram significativamente reduzidas $(P<0,0001)$. O grupo síndrome do intestino irritável não-infecciosa apresentou redução estatisticamente significante do escore total de sintomas $(P<0,0001)$. Além disso, a frequência de fezes foi significativamente reduzida $(P<0,0001)$ e a consistência das fezes melhoraram $(P<0,0001)$. Dor abdominal $(P<0,0001)$ e distensão abdominal foram significativamente reduzidas $(P<0,0001)$. Não houve diferença estatística entre o grupo síndrome do intestino irritável pós-infecciosa e o grupo síndrome do intestino irritável não-infecciosa sobre os resultados da pontuação total dos sintomas em 30 dias de terapia com mesalazina $800 \mathrm{mg} 3$ vezes ao dia $(P=0,13)$. Conclusão - O uso de mesalazina reduziu os principais sintomas da síndrome do intestino irritável pós-infecciosa e da síndrome do intestino irritável com diarréia não-infecciosa.

DESCRITORES - Enteropatias inflamatórias. Síndrome do intestino irritável. Mesalamina.

\section{REFERENCES}

1. Akiho M, Deng Y, Blennerhassett P, Kanbayashi H, Collins SM. Mechanisms underlying the maintenance of muscle hypercontractility in a model of postinfective gut dysfunction. Gastroenterology. 2005;129:131-41

2. Barbara G, De Giorgio R, Stanghellini V, Cremon C, Salvioli B, Corinaldesi R. New pathophysiological mechanisms in irritable bowel syndrome. Aliment Pharmacol Ther. 2004;2:1-9.

3. Barbara G, Stanghellini V, Cremon C, De Giorgio R, Corinaldesi R. Almost all irritable bowel syndromes are post-infectious and respond to probiotics: controversial issues. Dig Dis. 2007;25:245-8.

4. Bus PJ, Nagtegaal ID, Verspaget HW, Lamers CB, Geldof H, Van Krieken JH, Griffioen G. Mesalazine-induced apoptosis of colorectal cancer: on the verge of a new chemopreventive era? Aliment Pharmacol Ther. 1999;13:1397-402.

5. Chadwick VS, Chen W, Shu D, Paulus B, Bethwaite P, Tie A, Wilson I. Activation of the mucosal immune system in irritable bowel syndrome. Gastroenterology. 2002; $122: 1778-83$.

6. Connor BA. Sequelae of traveler's diarrhea: focus on post-infectious irritable bowel syndrome. Clin Infect Dis. 2005;41:S577-86.

7. Delvaux M. Role of visceral sensitivity in the pathophysiology of irritable bowe syndrome. Gut. 2002;51:i67-71

8. Dunlop SP, Jenkins D, Spiller RC. Distinctive clinical, psychological, and histological features of postinfective irritable bowel syndrome. Am J Gastroenterol. 2003;98:1578-83.

9. Dunlop SP, Colemam NS, Blackshaw E, Perkins AC, Singh G, Marsden CA, Spiller RC. Abnormalities of 5-hydroxytryptamine metabolism in irritable bowel syndrome. Clin Gastroenterol Hepatol. 2005;3:349-57.

10. Forbes A, Cartwright A, Marchant S, Mcintyre P, Newton M. Oral, modifiedrelease mesalazine formulations-proprietary versus generic [review article]. Aliment Pharmacol Ther. 2003; 17:1207-14.

11. Fox CC, Moore WC, Lichtenstein LM. Modulation of mediator release from human intestinal mast cells by sulfasalazine and 5-aminosalicylic acid. Dig Dis Sci. 1991;36:179-84.

12. Gwee KA, Leong YL, Graham C, McKendrick MW, Collins SM, Walters SJ, Underwood JE, Read NW. The role of psychological and biological factors in postinfective gut dysfunction. Gut. 1999;44:400-6.

13. Gwee KA, Collins SM, Read NW, Rajnakova A, Deng Y, Graham JC, McKendrick MW, Mooch hala SM. Increased rectal mucosal expression of interleukin $1 \beta$, in recently acquired post-infectious irritable bowel syndrome. Gut. 2003;52:523-6.

14. Lin HC. Small intestinal bacterial overgrowth: a framework for understanding irritable bowel syndrome. JAMA. 2004;292:852-8.
15. Liptay S, Bachem M, Häcker G, Adler G, Debatin KM, Schmid RM. Inhibition of nuclear factor kappa B and induction of apoptosis in T-lymphocytes by sulfasalazine. Br J Pharmacol. 1999;128:1361-9.

16. MacDermott RP. Progress in understanding the mechanisms of action of 5-aminosalicylic acid. Am J Gastroenterol. 2000;95:3343-5.

17. Marshall JK, Thabane M, Garg AX, Clark W, Meddings J, Collins SM. Intestinal permeability in patients with irritable bowel syndrome after a waterborne outbreak of acute gastroenteritis in Walkerton, Ontario. Aliment Pharmacol Ther. 2004;20:1317-22.

18. Neal KR, Barker L, Spiller RC. Prognosis in post-infective irritable bowel syndrome: a six year follow up study. Gut. 2002;51:410-3.

19. Reinacher-Schick A, Seidensticker F, Petrasch S, Reiser M, Philippou S, Theegarten D, Freitag G, Schmiegel W. Mesalazine changes apoptosis and proliferation in normal mucosa of patients with sporadic polyps of the large bowel. Endoscopy. 2000;32:245-54.

20. Sandborn WJ, Hanauer SB. Systematic review: the pharmacokinetic profiles of oral mesalazine formulations and mesalazine pro-drugs used in the management of ulcerative colitis. Aliment Pharmacol Ther. 2003;17:29-42.

21. Small RE, Schraa CC. Chemistry, pharmacology, pharmacokinetics, and clinical applications of mesalamine for the treatment of inflammatory bowel disease. Pharmacotherapy. 1994;14:385-98.

22. Spiller RC, Jenkins D, Thornley JP, Hebden JM, Wright T, Skinner M, Neal KR Increased rectal mucosal enteroendocrine cells, T lymphocytes, and increased gut permeability following acute Campylobacter enteritis and in post-dysenteric irritable bowel syndrome. Gut. 2000;47:804-11.

23. Spiller RC. Post-infectious irritable bowel syndrome. Gastroenterology. 2003;124:1662-71.

24. Spiller R, Campbell E. Post-infectious irritable bowel syndrome. Curr Opin Gastroenterol. 2006;22:13-7.

25. Spiller RC. Role of infection in irritable bowel syndrome. J Gastroenterol 2007;42:41-7.

26. Tromm A, Griga T, May B. Oral mesalazine for the treatment of Crohn's disease: clinical efficacy with respect to pharmacokinetic properties. Hepatogastroenterology. 1999;46:3124-35

27. Wahl C, Liptay S, Adler G, Schmid RM. Sulfasalazine: a potent and specific inhibitor of nuclear factor kappa B. J Clin Invest. 1998;101:1163-74.

28. Weber CK, Liptay S, Wirth T, Adler G, Schmid RM. Suppression of NF-kappaB activity by sulfasalazine is mediated by direct inhibition of IkappaB kinases alpha and beta. Gastroenterology. 2000;119:1209-18. 